\title{
NATURAL REGENERATION OF SITKA SPRUCE ON THE QUEEN CHARLOTTE ISLANDS
}

\section{WALTER F. MCCULLOCH}

The Queen Charlotte Islands group is composed of a number of small islands and two large ones-Graham Island in the north and Moresby in the south. From the 60 -mile wide base of a rough triangle at the top of Graham, the islands extend 175 miles southward to come to the apex of the triangle at the lower end of Moresby. The most prominent physical features are the ranges of mountains along the west coast rising to 3000 and 4000 feet. In geological history the rivers of the mainland have deposited sand at the base of these mountains, forming an extensive, flat plain on the north island which is now 25 to 50 feet above the sea. It bears a growth of jack pine. This plain rises gradually to rolling hills toward Skidegate Inlet. There are two rivers of consequence with their headwaters in this hill-country-the Yakoun and the Mamin-the former emptying directly into Massett Inlet near Port Clements, the latter into the same body of water by way of Juskatla Inlet. Moresby Island is entirely mountainous, greatly indented by fiords, and has no streams worthy of note.

Under the influence of the Japanese current, the climate is moist and equable, there being no very great variation between summer and winter temperatures. Snowfall is light, but precipitation varies from 55 in. in the drier parts of Graham to 115 in. in the wetter parts of Moresby.

In the latter years of the war there was an extensive exploitation under the direction of the Imperial Munitions Board, of Queen Charlotte Sitka spruce. Trees of this species attain remarkable size, the favorable climate providing optimum growing conditions. Exceptional diameter growth was found to be-one ring, one inch; average, five rings, one inch. Exceptional diameter and height, $12 \mathrm{ft}$. and 300; average, $3 \mathrm{ft} .4 \mathrm{ft}$., and $175 \mathrm{ft}$. After the Armistice there was no pressing need for this class of material and the tremendous activity of wartime became reduced to sporadic operations by hand loggers and small contractors, chiefly engaged in taking out pulp timber. These two classes of logging - for aeroplane stock and for pulp stock, differed greatly, as was found in a survey of the logged areas undertaken in 1927.

A reproduction study was carried out by the Research Division of the B.C. Forest Branch in that year. Over 2000 miles were travelled by the party, and every major cutting area of the war-time spruce logging was visited. An effort was made to determine the species, amount, and distribution of reproduction on the cut-over areas; and to determine the effect of various factors on the natural re-stocking of the cut-over areas. The lapse of a decade between years of logging and the time of examination, allowed ample time for adjustment of such factors as seedling mortality and it is assumed that 
the reproduction found there to-day will be fairly well indicative of the mature stand which may be expected to follow.

The method of survey was as follows: strips 0.1 chain wide and 10 chains or more in length were run over the cut-over areas; each unit of ten chains was divided into 2-chain sections and reproduction tallied separately for each of these sections. In each individual cutting examined, strips were arbitrarily selected to cover the most representative portion of the area-in most cases at right angles to the contour, from tide-water up the mountain side. On each 10-chain strip the following information was recorded: distance from seed trees or marginal timber; aspect; slope; soil type; original stand type; ground cover; when logged, by whom, how logged; disposal of slash; sketch of strip on key map. Reproduction was recorded in these classes: $0.1 \mathrm{ft}$., $1.2 \mathrm{ft}$., $2.4 \mathrm{ft}$., $4.6 \mathrm{ft}$., $6.8 \mathrm{ft}$., $8 \mathrm{ft}-2$ in. D.B.H., 2 in. -6 in., 6 in. -10 in., 10 in. 14 in. D.B.H.

\section{RESULTS OF THE SURVEY.}

The distribution of species over different areas, and number of seedlings per acre is shown below:

\section{TABLE I.}

No. of seedlings Percentage of logged area bearing: per acre Spruce Hemlock Cedar All Species

$\begin{array}{lllll}\text { Less than } 500 & 46 & 43 & 18 & 20\end{array}$

$\begin{array}{lllll}501-2000 & 38 & 36 & 70 & 30\end{array}$

More than $2000 \quad 16 \quad 21 \quad 12 \quad 50$

$\begin{array}{llll}100 & 100 & 100 & 100\end{array}$

If 500 seedlings per acre of all species is considered the minimum requirement for restocking it will be seen that $80 \%$ of the area has sufficient natural regeneration and that $20 \%$ has not restocked in a satisfactory manner. If 500 spruce per acre is considered the minimum requirement (on account of the superiority of this species) it is found that $54 \%$ is satisfactorily restocked. It is to be noted that this condition obtains only for the old aeroplane spruce cuttings, where the operator selected only the very finest stands, in which the productive quality of the site was superior and the percentage of spruce forming the stands was greater than most areas now being logged for pulp. Under this old selection cutting as it might be called, one half the area may be assumed to be restocking satisfactorily with spruce. What will happeni on the newer pulp operations is problematical. It is likely that the amount of all species and the percentage of spruce which will establish in a given period will be less than on the aeroplane spruce areas because of the smaller percentage of spruce in the original stands, and because of the greater size of the logging compartments, resulting in a decreased seed supply. The effect of the marginal stands upon the amount of reproduction is given as follows: 
TABLE II.

Distance from marginal

timber in chains. 2

No. of seedlings per

acre expressed in $\% 100$

$\begin{array}{rrrrrr}4 & 6 & 8 & 10 & 12 & 14 \\ 82 & 46 & 24 & 19 & 20 & 18\end{array}$

of number at 2

chains.

Basis $1550,1 / 50$ th acre tallies.

Beyond 10 chains there were not sufficient data to give reliable information. The greater number of seedlings found close to green timber emphasizes the importance of the timber at the margins of setting as a factor in seed supply; and that with the tendency under uncontrolled management for extensive clear cutting, some provision for seed supply is necessary.

There is no attempt made to dispose of slash in any of the operations on the Islands; in fact it is doubtful that any disposition by burning could be made, owing to the high humidity of this part of the fog-belt. Slash appears to be a derogatory factor in the re-establishment of spruce, either by causing too much shade, making adverse seed bed conditions, or for reasons which have not been determined. The following table gives the relation between the percentage of the ground covered by slash and the amount of reproduction appearing:

\begin{tabular}{|c|c|c|c|}
\hline \multicolumn{4}{|c|}{ TABLE III. } \\
\hline & $\begin{array}{l}\% \text { of } \\
\text { ground }\end{array}$ & $\begin{array}{l}\text { No. of } \\
\text { seedlings }\end{array}$ & $\%$ of \\
\hline Area & $\begin{array}{l}\text { Covered by } \\
\text { slash }\end{array}$ & $\begin{array}{l}\text { per } \\
\text { acre }\end{array}$ & spruce \\
\hline A & 5 & 9000 & $48 \%$ \\
\hline B & 5 & 690 & $50 \%$ \\
\hline C & 30 & 500 & $20 \%$ \\
\hline D & 100 & 20 & Nil \\
\hline E & 100 & 2 & Nil \\
\hline
\end{tabular}

The above table is based on 10-chain strips on each of five representative areas so merely indicates that a reduction in the amount of slash tends to increase the amount of reproduction and percentage of spruce in the mixture.

The survey seemed to indicate that the percentage of hemlock is increasing in the mixed stands-this is to be expected with the removal of the best spruce seed trees from within the stand, and from adjacent marginal timber.

Seed supply and seed bed conditions are probably the two most important factors affecting the reproduction of spruce in this type, but because of the multitudinous other factors influencing reproduction, and the difficulty of differentiating between them, such an empirical study as that undertaken in 1927, can do little beyond indicating in a general way, the causes for the conditions as found. The survey did show that there is, on the whole, good reproduction on the Islands, and fair reproduction of Sitka Spruce. 